\title{
Hybridity of Ukrainian Society in the years 2000-2012. Between Political Activity and Political Apathy
}

\begin{abstract}
It is difficult to characterize Ukrainian society as fully active or passive, as, on the one hand, public participation and involvement in political life as well as large mobilization in situations where civil interests are violated are clearly visible, and, on the other, we can notice a decrease of political activity as a consequence of these events.

The aim of the present work was to analyze and explain the specificity of the functioning of Ukrainian society in the years 2000-2012. The study was conducted with the author's own designed tool based on the concept of ideal types developed by Max Weber. The analysis of political apathy used a dissonant category of political activity and the conclusions were drawn on the basis of whether the legislation of Ukraine promotes an active attitude of society and the extent to which the provisions of the law are reflected in real involvement of Ukrainian citizens in political matters. The results show that participation of Ukrainian society in different forms of political activity does not entail its full realization, while the fact that Ukrainian citizens got involved in public affairs excludes the recognition of Ukrainian society as
\end{abstract}

1 Chair of the Northern Europe Countries, Faculty of Law, Management and Administration, Jan Kochanowski University in Kielce, Poland. 
fully apathetic. Thus, in the case of Ukraine, we are dealing with a hybrid society characterized by political activity with elements of political apathy.

\section{Keywords:}

political activity, political apathy, political participation, hybrid society, Ukrainian society

\section{INTRODUCTION}

It is difficult to characterize Ukrainian society as fully active or passive, as, on the one hand, public participation and involvement in political life as well as large mobilization in situations where civil interests are violated are clearly visible (e.g., student "Revolution on the Granite” in 1990, “Orange Revolution” in 2004, "Euromaidan" in 2014, a protest campaign "Ukraine without Kuchma" called an "incomplete revolution" at the beginning of 2000), and, on the other, we can notice a decrease of political activity as a consequence of these events. Therefore, the question arises: how should a society be described that is characterized by "bursts" of activism during revolution and recurring participation in elections coupled with a decline in political engagement?

The aim of the present work was to analyze and explain the specificity of the functioning of Ukrainian society in the years 2000-2012. The starting point of the time frame covered in the study is marked by the period of rising protests against the then President Leonid Kuchma (e.g., the protest campaign "Ukraine without Kuchma" or the so-called Cassette Scandal associated with the murder of a Ukrainian journalist Georgiy Gongadze in 2000). These events broke a period of public passivity of the first decade of the functioning of an independent Ukrainian state. The closing point for the analysis was parliamentary elections in 2012 when new leaders emerged in the Ukrainian political scene (Oleg Tyahnybok - party "Freedom", and Vitali Klitschko - party UDAR) and public involvement in the electoral process increased.

The study analyzed the functioning of Ukrainian society as well as compared the categories of political apathy and political activity. The main question [Q] concerned the extent to which Ukrainian society can be described as active, and the extent to which it is characterized by political apathy. The question was formulated in such a way as to allow the use of a dissonant category of political activity (characteristic of societies in democratic countries) and a category of political apathy (defining societies in authoritarian regimes) in research on the nature of 
Ukrainian society. The hypothesis [H] stated that the specificity of Ukrainian society lies in a balance between the features of political activity and political apathy, and, therefore, Ukrainian society can be described as hybrid by means of a new category of political activity with elements of political apathy.

\section{THE CONCEPT AND MEANING OF POLITICAL APATHY AND POLITICAL ACTIVITY}

Research comparing political activity and political apathy is a difficult task since the lack of apathy in a society does not entail public activity, and, conversely, inactivity does not entail apathy. It was thus necessary to operationalize both concepts in order to determine their possible relationship.

Researchers analyzing the passivity of society use different concepts such as political absenteeism, political alienation, or political apathy. Political apathy reflected in a passive attitude of society is treated as a dysfunction of democracy (see: DeLuca, 1995; Szczegóła, 2013b, pp. 173-186). When we compare political absenteeism with political apathy we are dealing with a certain dissonance as absenteeism is to be understood as non-participation of society in the act of voting. Political apathy, in turn, is characteristic of authoritarian regimes, where the electoral process is usually characterized by high voter turnout. In democratic states, participation in elections is a tool for the legitimacy of power (Lubecki, Szczegóła, 2007, pp. 74-92). Therefore, the concept of political apathy is much broader and can include both political absenteeism as well as political alienation; using these categories interchangeably is thus not justified. Krzysztof Korzeniowski (1999, p. 74) believes that low efficiency and a way of functioning of a new government with simultaneous high social expectations can lead to a situation in which a boycott of political life shows the following evolution of public sentiment: disappointment - frustration - alienation - apathy. The sequence shows that political apathy occurs after alienation, absenteeism, or passivity. Absence of extensive and intensive political mobilization is a specific example of the lack of interest in political life which can lead to alienation, isolation, discouragement and consequently - political apathy. On the other hand, Krystyna Skarżyńska (2002; 2005) claims that political activity involves any form of individual commitment aimed to exert some influence on the decisions of the government, either in the form of behavior toward a given political party and/or political position, or a kind of emotional involvement coupled with the raised interest in political issues. Therefore, according to Skarżyńska, political activity is a much broader concept, 
encompassing all forms of participation and commitment resulting from the interest in political life. Undertaking research on political activity that takes into account not only the political participation of a given society but also its involvement in political affairs is justified by the fact that political participation alone does determine the functioning of a democratic state (see: Wojtasik, 2012, pp. 112-113; Rose, Mossawir, 1967, p. 173; Szczegóła, 2013a, pp. 49-60).

\section{METHOD}

The study was conducted with the author's own designed tool based on the concept of ideal types developed by Max Weber (1985; 1995). The analysis of political apathy used a dissonant category of political activity and the conclusions were drawn on the basis of whether the legislation of Ukraine promotes an active attitude of society and the extent to which the provisions of the law are reflected in real involvement of Ukrainian citizens in political matters. Political activity was measured with three variables [Z]: $[\mathbf{Z} 1]$ - the possibility to form and act in various types of political groups (freedom of association); [Z2] - the possibility to participate in parliamentary and presidential elections (active and passive voting rights); [Z3] - the possibility to organize and conduct a referendum (legislation initiative). Research on the activity of Ukrainian society requires the analysis of legislation ensuring public political participation. The analysis of legal provisions enables the examination of social activity only from a legal point of view, which may not always reflect the reality. It was therefore necessary to analyze the implementation of the provisions of the law relating to the principle of political activity. To do so, the above-mentioned variables needed to be transformed using a correlation variable (Della Porta, Keating, 2008, pp. 253-254; Breen, Holm, Karlson, 2014), which, in a simplified way, can be performed by verifying legal provisions in research.

The verification of variable [Z1] (i.e., how the possibility to form and act in all kinds of political groups was realized) was conducted by analyzing indicators [X1] - the number of new parties, and [X2] - membership of citizens in political parties and other forms of associations. Variable [Z2] (the extent in which the possibility to participate in parliamentary and presidential elections was granted) was verified using indicators [X3] - turnout in presidential and parliamentary elections, and [X4] - participation in the elections of political parties. The last variable [Z3] (the degree to which the possibility to organize and conduct a referendum and start a legislative initiative was provided) was verified by analyz- 
ing indicators [X5] - organization of a referendum, as well as [X6] - possibility of submitting legislative proposals through a legislative initiative.

\section{POLITICAL ACTIVITY OF UKRAINIAN SOCIETY}

In order to examine the specificity of the political activity of Ukrainian society in the years 2000-2012, the level of citizens' political activity was studied by analyzing appropriate legal acts guaranteeing the following three possibilities.

The possibility to form and act in various types of political groups (freedom of association) - [Z1]. The realization of this possibility was analyzed based on the provisions included in the Law on Public Associations of 16 June 1992 (henceforth referred to as the Law of Ukraine on Public Associations) (Закон України Про об'єднання громадян) and the Law on Political Parties of 5 April 2001 (henceforth referred to as the Law of Ukraine on Political Parties) (Закон України Про політичні партії в Україні). The provisions ensuring the freedom of association are also included in Article 14 of the Constitution of Ukraine, which states that citizens have the right to associate in different types of associations (political parties and social organizations) with the purpose of realizing their common interests (Конституція України). The provisions of the Law of Ukraine on Public Associations (Art. 6,8) specify that participation in different kinds of associations is voluntary, and all their members' rights are equal. The functioning of public organizations is based on the principles of legality and transparency (Закон України Про об'єднання громадян).

It should be noted that the state financing of political parties, introduced in 2005 under the Law on the Introduction of State Financing of Political Parties (Закон України Про внесення змін, Art. 17-1-17-5), was granted only to those parties that crossed the electoral threshold in the previous election. However, under the Law on State Budget of Ukraine for 2008 the aforementioned provision was abolished, and the Constitutional Court of Ukraine declared it incompatible with the Constitution of Ukraine in Маy 2008 (Закон України Про Державний бюджет; Рішення Конституційного Суду України).

The possibility to participate in parliamentary and presidential elections - [Z2]. Relevant here are the provisions related to the right of registration and notification of candidates and political parties in elections. Analyzing the implementation of the right to stand in parliamentary elections, it should be noted that in accordance with Art. 38 sec. 1 of the Law of Ukraine on Elections of People's Deputies of Ukraine of 18 October 2001 (henceforth referred to as the 
Act of 2001) and the Law of Ukraine on Elections of People's Deputies of Ukraine of 25 March 2004 (henceforth referred to as the Act of 2004) it was only these political groups that were registered at least one year prior to elections that could nominate their candidates [Закон України Про вибори народних депутатів України (2001); Закон України Про вибори народних депутатів України (2004), Art. 10 sec. 1]. However, the Law of Ukraine on Elections of People's Deputies of Ukraine of 17 November 2011 (henceforth referred to as the Act of 2011) did not renew this provision, which, to a large extent, can be regarded as an encouragement to political activity [Закон України Про вибори народних депутатів України (2011)]. Other provisions that pertain to the present discussion refer to the time within which political groups can nominate their candidates: the ordinance of 2001 introduces a 21-day period (Art. 38 sec. 4), the ordinance of 2004 - a 40-day period (Art. $55 \mathrm{sec}$. 2), and the provisions of 2011 - only a 12-day period (Art. 52 sec. 1). A short time available for the registration of candidates for deputies may have negative impact on the mobilization of society to implement the right to stand in elections.

An important issue that also affects the electoral participation of Ukrainian citizens relates to the provisions on the conditions for collecting signatures or paying a registration fee when registering candidates for deputy. Ukraine abandoned the requirement to collect citizens' signatures and introduced a financial deposit instead. The Law of 2001 states that an election deposit shall be in the amount of fifteen thousand minimum citizens' incomes in the case of political parties and sixty minimum citizens' incomes in the case of candidates for deputy (Art. 43 sec. 1-2). The ordinance of 2004 introduces an election deposit for parties in the amount of two thousand minimum citizens' incomes (Art. 59 sec. 1) and the Law of 2011 repeats this provision (Art. 56 sec. 1-2). However, in a single-mandate district, the amount of a financial deposit shall not exceed twelve minimum citizens' incomes. This confirms that the amount of deposits is relatively high, given the fact that a deposit is refunded only to those parties that will receive a mandate, in other cases, it funds the State Budget of Ukraine.

The possibility to organize and conduct a referendum (a legislation initiative) - [Z3]. The Constitution does not provide for the possibility to submit a bill proposal by the citizens of Ukraine (the initiative is given to the President of Ukraine, deputies, the Cabinet of Ministers of Ukraine, and the National Bank of Ukraine). In the case of a referendum, the decision to convene a referendum is made by the parliament or the president; however, a referendum may also be called upon the request of at least three million citizens of Ukraine, on condition that signatures supporting the call of a referendum are collected in no less than two-thirds of the 
districts of the state and in the number of not less than one thousand from each (Конституція України, Art. 93).

More specifically, the issues concerning the organization and conduct of referendums in Ukraine are regulated by the Law on All-Ukrainian and Local Referendums of 3 July 1991 (Закон України Про всеукраїнський референдум). The law (Art. 3.5) specifies that the subject of All-Ukrainian referendum may be: approval of the Constitution of Ukraine, its provisions, as well as introduction of changes to the Constitution of Ukraine; adoption or amendment of the legislation of Ukraine; issues related to the joining or leaving the structures of federative or confederative state formations (Art. 4). Reconsideration of a question earlier submitted to a referendum may be subject to public voting no earlier than five years after the day the referendum on these questions was conducted (All-Ukrainian referendum) (Art. 9).

\section{RESULTS}

The analysis of the Ukrainian legal provisions relating to public political activity gave the following results: [Z1] The Ukrainian legislation, to a large extent, guarantees Ukrainian citizens the possibility to form and act in political groups. [Z2] Although citizens have the right to participate in presidential and parliamentary elections, the provisions relating to the registration of candidates for deputy and a relatively high amount of deposit mean that this possibility is not fully realized. [Z3] Legislation guarantees Ukrainian citizens the right to participate in all kinds of referendums and a possibility to call a referendum on their own initiative. However, the law of Ukraine does not provide for the possibility of submitting a bill proposal by the citizens. Thus, despite some limitations, the Ukrainian legislation guarantees the citizens of Ukraine the realization of the three possibilities [Z]. A further discussion needed to take into account the real extent in which a given possibility guaranteed by the Ukrainian legislation was realized.

[X1] The largest number of political parties was registered in 2005, namely 25. The reason for this phenomenon might be the mobilization of civil society as a result of the "Orange Revolution". In 2000, 12 new parties were registered2; in 2001-7, in 2002-2, in 2003-2, in 2004-4, in 2005-24, in 2006-11, in 2007-4,

2 It should be noted that this is the situation to date, representing political parties currently registered in Ukraine; the number does not include parties that have ceased to exist or operate within the structures of a different group now. 
in 2008-18, in 2009-12, in 2010-12, in 2011-13, and in 2012-7 (Політичні партії. Державна реєстраційна служба України). It should be noted that the provisions relating to the introduction of statutory financing of political parties did not affect the number of newly registered parties.

[X2] In 2008, a study conducted by the Razumkov Center showed that $4.7 \%$ of Ukrainians declared membership in a political party (Соціологічне опитування: Чи можна про Вас сказати, що Ви є членом політичної партії?). Research of the Institute of Sociology of the National Academy of Sciences of Ukraine indicated that the involvement of citizens in the activity of political parties is relatively low (Якименко, 2002). In 2000, 82.9\% of respondents claimed that they were not members of any social or political group, $0.1 \%$ of respondents - did not give any answer, and $0.8 \%$ marked their affiliation to a political party. The above findings reveal that $16.2 \%{ }^{3}$ of respondents indicated that they were members of other types of organizations (trade unions, associations, social movements, etc.). In 2002, 2.2\% of respondents declared their affiliation to a political party and $13.7 \%$ to a social association. The results of 2006 show that $4.6 \%$ of citizens were party members and $11.7 \%$ belonged to non-governmental organizations. Two years later, $2.5 \%$ of respondents marked their membership in a political party and $13.8 \%$ in a social association. In 2011, the number of respondents confirming their membership in political parties declined to $1.4 \%$, and only $8 \%$ claimed that they were members of non-governmental organizations. In 2012, 2.2\% of the surveyed citizens belonged to political parties while $11.8 \%$ to various kinds of associations (Українське суспільство 1992-2012, 2012, р. 535).

[X3] It is noteworthy that in each successive election to the Verkhovna Rada of Ukraine there was a decline in voter turnout. In 2002, it amounted to 69.2\%, in 2006 - to $67.6 \%$, in 2007 - to $62 \%$, and in 2012 - to $57.98 \%$. In the 2004, presidential election turnout was $75 \%$ in the first round, $80.6 \%$ in the second round, and $77.1 \%$ in the third round. The 2010 elections saw the following voter turnout: $66.7 \%$ (first round) and 69.15\% (second round) (Громадська організація “Інститут політики” Вибори-2010). Despite declining voter turnout in parliamentary elections, it is still at a very high level. In the present discussion, the level of voter turnout can

3 The percentage of people involved in associations could have been calculated by summing up the results of all forms of participation, however the respondents could indicate it if they were involved in several forms of associations, and thus this would not have been an accurate indicator. Therefore, from $100 \%$ I subtracted the percentage of people who did not belong to any social group or political party, next I subtracted the percentage of people who did not respond at all, and finally I subtracted the percentage of people belonging to political parties. The received percentage reflects the number of respondents who belonged to social organizations. 
be considered a verification of the possibility of Ukrainian citizens to participate in the electoral process. However, given the attempted manipulation of election results during the "Orange Revolution" and reports of fraud from the opposition, it is reasonable not to take into account the [X3] result as an indicator of full realization of the possibility of public participation in elections.

[X4] Sixty-one subjects participated in the 2002 parliamentary elections (including 12 blocks and 49 parties). The next 2006 elections saw a decline in the number of registered subjects - 45 ( 25 parties and 20 blocks). In turn, the number of subjects decreased more than twice in 2007 as only 20 subjects were registered to run in the election (including 10 blocks and 10 parties). The reason for such a considerable decline is to be sought in the fact that the 2007 election was an early election. The 2012 election witnessed a significant increase in the number of election subjects - 87 political parties (Політичні партії, Державна реєстраційна служба України).

[X5] A referendum as a means for consulting government's actions with society may, in some cases, become a tool to legitimize undemocratic solutions. President Kuchma ordered the holding of a referendum on 16 April 2000 in order to seek Ukrainian citizens' opinion on certain issues (Дмитричева, 2004). Kuchma’s intention, however, was to extend the competence of the President. Several issues were submitted to a referendum; among others, completing Article 90 of the Constitution of Ukraine with the following content: the President of Ukraine may order the early dissolution of the parliament if the Verkhovna Rada of Ukraine fails to form a majority within one month, or if it fails to adopt the state budget of Ukraine prepared and submitted in due form by the Cabinet of Ministers of Ukraine in three months. Also, attempts were made to reduce the number of deputies from 450 to 300 and introduce the Second Chamber of Parliament. However, despite a positive opinion of more than 25 million voters in 2000, no changes were implemented on the basis of the judgment of 27 March 2000 of the Constitutional Court of Ukraine, which found two of the six issues presented for consideration in the referendum unconstitutional (one concerning the lack of citizens' trust in parliament and the other relating to the adoption of the Constitution through a referendum) (Як відбувався всеукраїнський референдум 2000 року). [X6] The Ukrainian legislation does not grant a legislative initiative to the citizens of Ukraine.

After taking into account all the indicators and conditions, the results are as follows: indicator [X1] was fulfilled as the possibility to form new parties was realized; [X2] was also met since the public participation in political and social groups was allowed; indicator [X3] was only partially fulfilled as, although the 
public took part in parliamentary and presidential elections, there was an attempted manipulation of the election results; [X4] was fully realized as political parties were involved in the election process; indicator [X5] was fulfilled partially since a referendum gives the government the power to legitimize their actions (there are though effective mechanisms to counteract such measures); indicator [X6] was not met because the public lacks an instrument of legislative initiative. Thus, summing up the above results, the real dimension of the political activity of Ukrainian society is not fully implemented. The comparison of the legal situation with the actual state of affairs reveals that although the Ukrainian legislation contains provisions enabling the public to engage in political activity, this dimension is not realized to a full extent.

\section{CONCLUSION}

The present paper shows the results of the research I conducted on the political activity of Ukrainian society in the years 2000-2012 based on the analysis of two variables: the provisions of the law and their implementation in order to determine the actual extent to which political activity is undertaken. The findings made it possible to verify a specific hypothesis $[\mathbf{H}]$ stating that Ukrainian society can be described as hybrid through a new category of political activity with elements of political apathy.

The results show that participation of Ukrainian society in different forms of political activity does not entail its full realization, while the fact that Ukrainian citizens got involved in public affairs excludes the recognition of Ukrainian society as fully apathetic. Thus, in the case of Ukraine, we are dealing with a hybrid society characterized by political activity with elements of political apathy.

\section{References:}

Breen, R., Holm, A., Karlson, K.B. (2014). Correlations and Nonlinear Probability Models. Sociological Methods \& Research, 43 (4), 571-605. Retrieved from: http://smr. sagepub.com/content/43/4/571.

Della Porta, D., Keating, M. (2008) (eds.). Approaches and Methodologies in the Social Sciences. A Pluralist Perspective. Cambridge: Cambridge University Press.

DeLuca, T. (1995). The Two Faces of Political Apathy. Philadelphia: Temple University Press.

Korzeniowski, K. (1999). Między rewolucją a normalnością. Rzecz o alienacji politycznej 
na przełomie dekad. In: B. Wojciszke, M. Jarymowicz (eds.), Psychologia rozumienia zjawisk społecznych (pp. 61-78). Warszawa-Łódź: WN PWN.

Lubecki, J., Szczegóła, L. (2007). O źródłach apatii politycznej w transformującym się społeczeństwie. In: J. Garlicki (ed.), Społeczne uwarunkowania transformacji systemowej w Polsce (Studia politologiczne 11). Retrieved from: http://biblioteka.oapuw.pl/ jacek-lubecki-lech-szczegola-o-zrodlach-apatii-politycznej-w-transformujacym-siespoleczenstwie-studia-politologiczne-vol-11/.

Rose, R., Mossawir, H. (1967). Voting and Elections: A Functional Analysis. Political Studies, 15 (2), 173-201.

Skarżyńska, K. (2002). Aktywność i bierność polityczna. In: K. Skarżyńska (ed.), Podstawy psychologii politycznej. Warszawa: IP PAN.

Skarżyńska, K. (2005). Człowiek a polityka. Zarys psychologii politycznej. Warszawa: Wydawnictwo Naukowe Scholar.

Szczegóła, L. (2013a). Bierność obywateli. Apatia polityczna w teorii demokratycznej partycypacji. Warszawa: ELIPSA Dom wydawniczy.

Szczegóła, L. (2013b). Dysfunkcje dyskursu wokół apatii politycznej w Polsce. Studia socjologiczne, 208, 173-186.

Weber, M. (1985). Obiektywność poznania w naukach społecznych. In: A. Chmielecki, S. Czerniak, J. Niżnik, S. Rainko (eds.), Problemy socjologii wiedzy (p. 81-88). Warszawa: Państwowe Wydawnictwo Naukowe.

Weber, M. (1995). Szkice z socjologii religii. Warszawa: Książka i Wiedza.

Wojtasik, W. (2012). Wybrane uwarunkowania aktywności wyborczej. In: D. Karnowska, J. Nocoń (eds.), Obywatel - instytucje - władza na przełomie XX i XXI wieku. (p. 109-123). Toruń: Wydawnictwo MADO.

Дмитричева, О. (2004). День реформи конституції, “Дзеркало тижня. Україна” 25.04.2004. Retrieved from: http://gazeta.dt.ua/ARCHIVE/den_reformi_konstitutsiyi. html.

Закон України Про вибори народних депутатів України (2001) (Відомості Верховної Ради України (ВВР), 2001, № 51-52, ст. 265). Retrieved from: http://zakon3.rada. gov.ua/laws/show/2766-14.

Закон України Про вибори народних депутатів України (2004) (Відомості Верховної Ради Украӥни (ВВР), 2004, № 27-28, cm. 366). Retrieved from: http://zakon4.rada. gov.ua/laws/show/1665-15.

Закон України Про вибори народних депутатів України (2011) (Відомості Верховної Ради України (ВВР), 2012, № 10-11, ст. 73). Retrieved from: http://zakon2.rada.gov. ua/laws/show/4061-17.

Закон України Про внесення змін до деяких законодавчих актів України у зв’язку із запровадженням державного фінансування політичних партій в Україні (Відомості Верховної Ради України (ВВР), 2004, N 15, ст. 218). Retrieved from: http://zakon4. rada.gov.ua/laws/show/1349-15.

Закон України Про всеукраїнський референдум (Відомості Верховної Ради (BBP), 2013, № 44-45, ст. 634). Retrieved from: http://zakon4.rada.gov.ua/laws/ show/5475-17.

Закон України Про Державний бюджет України на 2008 рік та про внесення змін 
до деяких законодавчих актів України (Відомості Верховної Ради України (ВBP), 2008, N 5-6, N 7-8, ст. 78). Retrieved from: http://zakon1.rada.gov.ua/laws/ show/107-17/page.

Закон України Про об’єднання громадян (Відомості Верховної Ради України (ВВР), 1992, N 34, cm. 504). Retrieved from: http://zakon0.rada.gov.ua/laws/show/2460-12. Закон України Про політичні партії в Україні (Відомості Верховної Ради України (BBP), 2001, N 23, cm. 118). Retrieved from: http://zakon4.rada.gov.ua/laws/ show/2365-14.

Конституція України (Відомості Верховної Ради України (ВВР), 1996, № 30, ст. 141. Retrieved from: http://zakon4.rada.gov.ua/laws/show/254\%D0\%BA/96\%D0\%B2\%D1\%80.

Політичні партії, Державна реєстраційна служба України. Retrieved from: http://www. drsu.gov.ua/party.

Рішення Конституційного Суду України, Справа N 1-28/2008. Retrieved from: http:// zakon2.rada.gov.ua/laws/show/v010p710-08/ed20120419.

Соціологічне опитування: Чи можна про Вас сказати, що Ви є членом політичної партії? Centrum Razumkova. Retrieved from: http://www.uceps.org/ukr/poll. php?poll_id=347.

Українське суспільство 1992-2012, Стан та динаміка змін. Соціологічний Моніторинг, Членом з якої громадької або політичної організації ви є?, Інститут соціології НАН України Киів 2012. Retrieved from: http://i-soc.com.ua/institute/soc-mon-2012. pdf.

Як відбувався всеукраїнський референдум 2000 року, Громадська організація «Інститут політики». Retrieved from: http://polityka.in.ua/info/13.htm.

Якименко, Ю. (2002). Громадянська активність в Україні: чи приречені ми мати те, що маємо? Дзеркало тижня. Україна, 25.10.2002. Retrieved from: http://gazeta. dt.ua/POLITICS/gromadyanska_aktivnist_v_ukrayi-ni_chi_prirecheni_mi_mati_te,_ scho_maemo.html. 